\title{
Growth and Yield Adaptation of Cowpea Varieties Sown as Early- and Late-Rainy Season Crop in the Rainforest and Derived Savanna Agroecologies of South-West Nigeria
}

\author{
Agele SO*, Aiyelari OP, Famuwagun Band Oyewusi IK \\ Department of Crop, Soil \& Pest Management, Federal University of Technology, Nigeria
}

Submission: May 15, 2018; Published: July 09, 2018

"Corresponding author: Agele SO, Department of Crop, Soil \& Pest Management, Federal University of Technology, CSP SAAT, FUT, Akure, Nigeria, Tel: + 2348035784 761; Email: ohiagele@yahoo.com, soagele@futa.edu.ng

\begin{abstract}
Experiments were conducted on the field to evaluate the responses of growth and yield of cowpea varieties to the prevailing soil and weather conditions of the early- and late- rainy seasons between 2013 and 2015 in a rainforest and forest-savanna transition zones of south west Nigeria. The experiments were a $2 \times 2 \times 6$ factorial combination location, seasons of sowing and variety arranged in randomized complete block design (RCBD) with three replicates. The cowpea varieties were IT98K-205-8, Ife Brown, IT96D-610, IT98K-573-2-1, Oloyin Brown and IT97K-568-18. The early and late rainy season crops were sown in April and Septemberof 20132014 and 2015. The respective early and later parts of the early and late rainy seasons were characterized by dry spell (drought) situations which subjected cowpea sown in the early and late seasons subjected their pre- and post-flowering development phases to contrasting environmental conditions. These conditions appeared to have affected biomass accumulation and seed yield characters in the cowpea cultivars evaluated. Significant differences were found among the cowpea varieties for seed yield and harvest index both in Akure and Ado-Ekiti locations. Results showed that the late rainy season crops out yielded the early rainy season crops and Ado-Ekiti location gave higher seed yield (58kg/ha) compared to Akure location (40 kg/ha).The interaction between variety and season shows thatthe best performing variety was IT98K-573-2-1 (65.1 kg/ha)in the early rainy season while Oloyin Brown was better in the late rainy season $(68.0 \mathrm{~kg} / \mathrm{ha})$.The least performing variety for both seasons was IT98K-205-8 (26.8kg/ha).The poor performance of IT98K-205-8 across all seasons may be due its inability to adapt to weather conditions. The earliness character (days to $50 \%$ flowering) enabled cowpea plants to flower, pod fill and mature early and therefore escape the dryness of November and December. The highest seed yields recorded for IT98K-573-2-1 and Oloyin Brown. Cowpea varieties, IT98K-573-2-1 and Oloyin Brown gave the highest seed yields in both seasons and locations compared with the other varieties. In this study, IT98K-573-2-1 and Oloyin Brown variety are suitable for sowing in the study area because of their combined ability to produce high seed yields and adapt to the soil and weather conditions of the sowing seasons. These varieties are recommended for sowing as early and late rainy season crops in the study area.
\end{abstract}

Keywords: Cowpea;Varieties;Adaptation;Seasons;Weather;Agroecology;Productivity

\section{Introduction}

Cowpea [Vigna unguiculata(L.) Walp.] is an important food legumein the tropical and sub-tropical regions. Of the world total area of about 14 million hectares planted with cowpea, West Africa alone accounts for about 9 million hectares [1]. Cowpea contains more than $25 \%$ protein in its seeds, as well as in young leaves. It is a major source of protein, minerals and vitamins in human diets as well as livestock feed. It is particularly a nutritious fodder for livestock and is often grown in rain-fed agriculture receiving at least $600 \mathrm{~mm}$ annual rainfall [2]. Improved varieties of cowpea with resistance or tolerance to biotic and abiotic stresses had been developed [3]. Such varieties especially benefit resource poor farmers under low input insecticides and fertilizers [4]. There is therefore, increasing need for genetic improvement and development of cowpea varieties to meet the growing need for human and livestock consumption. Varietal requirements of cowpea in terms of plant type, seed colour, maturity date and usage patterns are extremely diverse from region to region, making breeding programs for cowpea more complex than for other crops and no single variety can be suitable for all conditions $[2,5,6]$. To sustain this level of production, improving the productivity of cowpea may involve the use of improved varieties and cultural practices, and understanding adaptation of cowpea to agro-ecological conditions [5]. 
The humid rainforest zone of Nigeria has a growing season length that is longer than 200 days with more variability of the average date of onset of the rains than its cessation [7]. Mean daily temperatures during the growing seasonsvaries by only a few degrees from 27-290C and day length on 21 June varies from 13.37 to $13.68 \mathrm{~h} /$ dayat 8 and $130 \mathrm{~N}[8,9]$. Cropping opportunities are provided by the earlier part of the rainy (first sowing) season before the rainfall is fully established and late sowing season falls within the second mode of rainfall distribution [7]. The optimal sowing date of cowpea in the rain forest zone of Nigeria is at the beginning (onset) of the rains (before rainfall is fully established), crop's reproductive growth phase particularly seed maturity falls into the short dry spell which marks the end of the first bimodal rainfall $[2,10]$. The dry spellcharacterized by abundant sunshine withlittle or no rainfall occurs at the close of the first modal distribution. The late rainy season falls within the second mode of rainfall distribution. The late rainy season (September to December) is occasioned by short rainy season, limiting soil moisture status, high soil temperatures, irradiance and atmospheric vapour deficits. There are variations in soil water and thermal regimes of the early part of the rainy season (early vegetative phase of growth) and in the later part of the late cropping season (terminal drought situation). The inclusion of timing of dry spells to growth stages of crops especially rainfall-based analyses of dry spell occurrence makes dry spell analyses very relevant to farm management.Barron et al. [11] termed agricultural dry spell as a period of consecutive dry days resulting in a soil water deficit causing crop water stress. Farmers are more concerned with the occurrence and timing of actual crop water stress as they affect growth stages most likely to suffer from water stress.These environmental events have profound influence on growth and yield of crops[7].It is therefore imperative to assess genotypic adaptation in cowpea tosoil and especially the weatherconditions of the early and late sowing seasons in the humid rainforest zone of south west Nigeria.

In plants, the sensitivity of physiological processes to the hydrothermal regimes is reported [12-14]. Soil moisture stress and temperature regimes affect phenology and crop growth duration [15] as well as the rate of leaf growth and the enlargement of canopy during crop growth cycle [16]. In crops unfavourable growing environment imposes assimilate limitation, restricts pollination and decreases kernel set $[12,17,18]$. In addition to the prevention of pollination, low water potentials during grain filling can arrest ovary growth and cause embryo abortion [13]. Traits such as biomass accumulation, leaf area development are important to crop yield under variable soil water and thermal regimes during growth [19]. Plant possess traits which enhance the fitness of physiological functions, such traits are important in setting tolerance limit to extreme environmental conditions $[18,20,21]$ for survival and productivity under crop variable agroecosystems and sowing seasons $[7,19]$. The understanding of the values of these traits is of utmost importance in the strategies to improve genotypic adaptation and hence the productivity of crops in areas and seasons that are characterized by varying degrees of soil moisture deficits and temperature extremes at some stage of growth cycle.

Studies of crop-weather relationships are necessary to define probabilities of occurrence of extreme weather events and the effects on crops. Such relationships would find use in the assessment of the fitness/suitability of major staple crops to different localities and for projections on their productivity potentials. In order to assess cultivars that are well adapted to the diverse growing ecologies/environments and seasons of planting, it is necessary to identify crop varietal traits that are needed in cultivars foradaptation and performance under the prevailing weather and soil conditions of the growing season. This study appraised the effects of weather events of the early part of the rainy and the late rainy seasons (terminal drought situation) on the performance of selected cowpea genotypes. The objectives were to examine growth and seed yield in cowpea cultivars grown under contrasting growing seasons characterized by occurrence of variable soil and air temperatures, vapor pressure deficits (atmospheric humidity), evaporative demand and soil moisture regimes in the pre- and post-flowering growth phases on the field.

\section{Materials and Methods}

Field experiments were conducted to evaluate the responses of growth and yield of cowpea varieties to the prevailing soil and weather conditions of the growing season. The experiments were conducted at the Teaching and Research Farm of the Federal University of Technology, Akure and the Federal Polytechnic Ado Ekiti Research Experimental Station, Ado Ekiti, Nigeria, between January 2012 and December 2015. The selected cowpea varieties namely IT98K-205-8, Ife Brown, IT96D-610, IT98K-573-2-1, Oloyin Brown and IT97K-568-18, were obtained from IITA, Ibadan, Nigeria. The treatments were laid out in a Randomized Complete Block Design. The rainy and late season crops were sown in April and September respectively. The site was manually weeded and pulverized while the seeds of selected cowpea cultivars were sown in April and September in both planting locations. Seeds were sown at a spacing of $60 \mathrm{~cm}$ between the rows and $30 \mathrm{~cm}$ within the rows in a field plot of $20 \mathrm{~m} \times 20 \mathrm{~m}$ separated into plots. The cowpea cultivars were randomly allocated to field plots and each variety was replicated three times.

\section{Experimental sites and conditions}

Experiments were conducted during the early and late rainy seasons at two locations: at the Teaching and Research Farm of the Federal University of Technology, Akure (FUTA) between2013 and 2015 and the Federal Polytechnic Ado Ekiti in 2015. Akure experiments were conducted in the early and late rainy seasons of 2013, the early rainy season of 2014 and late rainy season of 2015. At Ado-Ekiti location, trials were conducted early and late rainy seasons of 2015 . 


\section{Pre-cropping soil sampling and analysis}

The first five plantings were established in the early and late rainy seasons at FUTA research farm on fields prepared from fallow vegetations of siam weed and milk weed (Chromolaena odorata and Euphorbia heterophyla).The Ado Ekiti site was on fallowed land dominated by milk weed, Glyricidia sepium and sunflower (Halianthus annuus). Soil samples were collected from each experimental site prior to land preparation by random sampling. Core samples taken to a depth of $15 \mathrm{~cm}$ with soil auger, were bulked to form composite samples. The samples were mixed thoroughly, air-dried for three days, crushed and sieved through $2 \mathrm{~mm}$ sieve to remove rocks and other debris. The portion of the soil for determination of nitrogen was sieved through $0.5 \mathrm{~mm}$ sieve to increase the surface area. The samples were subjected to routine labouratory analysis. The results are presented in Table1.

Table 1: Pre- planting soil physical and chemical properties at experimental sites in Akure and Ado-Ekiti (Field experiments).

\begin{tabular}{|c|c|c|}
\hline \multirow{2}{*}{ Soil properties } & \multicolumn{2}{|c|}{ (Values) } \\
\cline { 2 - 3 } & Akure & Ado-Ekiti \\
\hline Sand (\%) & 70.4 & 84.4 \\
\hline Silt (\%) & 6 & 7.28 \\
\hline Clay (\%) & 23.6 & 8.32 \\
\hline Bulk density(g/cm $\left.{ }^{3}\right)$ & 1.42 & 1.39 \\
\hline pH(water) & 6.9 & 6.2 \\
\hline Soil moisture & 13.99 & 13.42 \\
\hline Total Nitrogen (\%) & 0.19 & 0.62 \\
\hline Na(cmol/kg) & 0.02 & 0.18 \\
\hline K (cmol/kg) & 0.02 & 0.32 \\
\hline Ca (cmol/kg) & 1.47 & 2.47 \\
\hline Mg.(cmol/kg) & 4.2 & 1.23 \\
\hline Organic carbon (\%) & 2.33 & 0.72 \\
\hline Hydrogen ion & 1.04 & 0.24 \\
\hline Al2+ & 0.4 & 4.02 \\
\hline CEC & 3.28 & 4.1 \\
\hline
\end{tabular}

\section{Experimental design and treatments}

Field experiments were conducted in the early and late rainy seasons between 2013 and 2015 at both locations: The Teaching and Research Farm of the Federal University of Technology, Akure (FUTA) and the at the Federal Polytechnic Teaching and Research Farm, Ado-Ekiti. The experiments were a 2x2x6 factorial combination location, seasons of sowing and variety arranged in randomized complete block design (RCBD) with three replicates in a $20 \times 20 \mathrm{~m}$ field plot. The cowpea varieties were IT98K-205-8, Ife Brown, IT96D-610, IT98K-573-2-1, Oloyin Brown and IT97K-568-18. The early and late rainy season crops were sown in April and September2013, 2014 and 2015. The treatments were based on planting cowpea varieties in the early rainy season and the late rainy seasons of each year. The screenhouse experiment which consisted of $6 \times 3 \times 2$ factorial combination of cowpea varieties, watering regimes and rhizobial inoculation examined the interplay of soil moisture regimes and rhizobial inoculation on root nodule formation, growth and seed yield of cowpea.

\section{Procurement of plant materials}

The selected cowpea varieties, IT98K-205-8, Ife Brown, IT96D-610,IT98K-573-2-1, Oloyin brown and IT97K-568-18, were obtained in a single batch from IITA, Ibadan, Nigeria. The six varieties were chosen on the basis of contrasting maturity period (days to flowering/anthesis) and seed yield. The growth and yield performance of the varieties were evaluated on the field in the respective rainy and late sowing seasons

1. The characteristics of the cowpea varieties used for the experiment

2. IT98K-205-8-Smooth, semi-erect, globose with a maturity period of 65-72 days white seeded

3. Ife Brown-Smooth, semi-erect, ovoid with a maturity period of 60-70 days brown seeded

4. IT96D-610-Smooth semi-erect, rhomboid with a maturity period of 65-75 days brown seeded

5. IT98K-573-2-1- Creeping, ovoid with a maturity period of 70-80 days white seeded

6. Oloyin Brown-Creeping, globose with a maturity period of 70-80 days brown seeded

7. IT97K-568-18- Smooth, creeping ovoid with a maturity period of 65-85 days brown seeded

\section{Weed control}

Pre-emergent herbicide was applied at planting using a combination of grammozone and atrazine to remove both grass and legume weeds. Manual weeding was carried out at two weeks interval after establishment at all locations.

\section{Pest control}

Season and time of planting was found to significantly influence insect damage, quality of harvest and yield of cowpea during the period of growth. The greatest insect damage occurred during the late rainy season of planting. Insect pests are the most important yield reducing factors in cowpea. The pre-flowering insects such as aphids and leaf hoppers were controlled along with the post flowering pests such as Maruca (pod boring insects). Three spraying regimes were carried out at bud initiation, flowering and podding stage in order to reduce insect pest infestation. Control of insect pest of cowpea was carried out by spraying the fields at intervals with Cypermethrine at 0.4-0.8 liters/ha.

\section{Harvesting}

Cowpea pods were harvested when fully matured and dried by handpicking at intervals. Several harvesting was done because of the nature and maturity variations of the varieties used for the experiment. The pods do not mature at the same time because 
of the staggered flowering period and varietal difference. After harvest, cowpea pods were dried; threshed and clean seeds were separated from the chaff or haulms through winnowing.

\section{Plant and soil measurements}

Six improved cowpea varieties Seeds were sown at a spacing of $60 \mathrm{~cm}$ between the rows and $30 \mathrm{~cm}$ within the rows in a field plot of $20 \mathrm{mx} 20 \mathrm{~m}$ separated into plots. The number of plants per hill was two. Weeds were controlled by hand weeding as at when necessary. Insect pests were controlled by the application of Karate R insecticide at the rate of 0.4-0.8 liters/ha on three occasions beginning with floral bud initiation.
The particle analysis of the soils at the site of experiment was determined by the hydrometer method while $\mathrm{pH}$ was determined in a 1:1 soil water suspension using a $\mathrm{pH}$ meter. Organic matter was determined by Walkley and Black [22] method through chronic acid digestion. Total Nitrogen was determined using micro-Kjedahl procedure [23],availableP was extracted using Bray P-1 extractant $[24,25]$ while the amount of $P$ in the extract was measured using blue coloration method on a spectrophotometer.The exchangeable bases( $\mathrm{K}, \mathrm{Ca}, \mathrm{Mg}$ and $\mathrm{Na}$ ) were extracted with $\mathrm{IM} \mathrm{NH}_{4} \mathrm{OAC}$ atpH $\mathrm{H}_{7}$, the amount of $\mathrm{K}$ in the extracts was determined on flame photometerwhile $\mathrm{Ca}$ and $\mathrm{Mg}$ were determined using the EDTA filtration method [23].

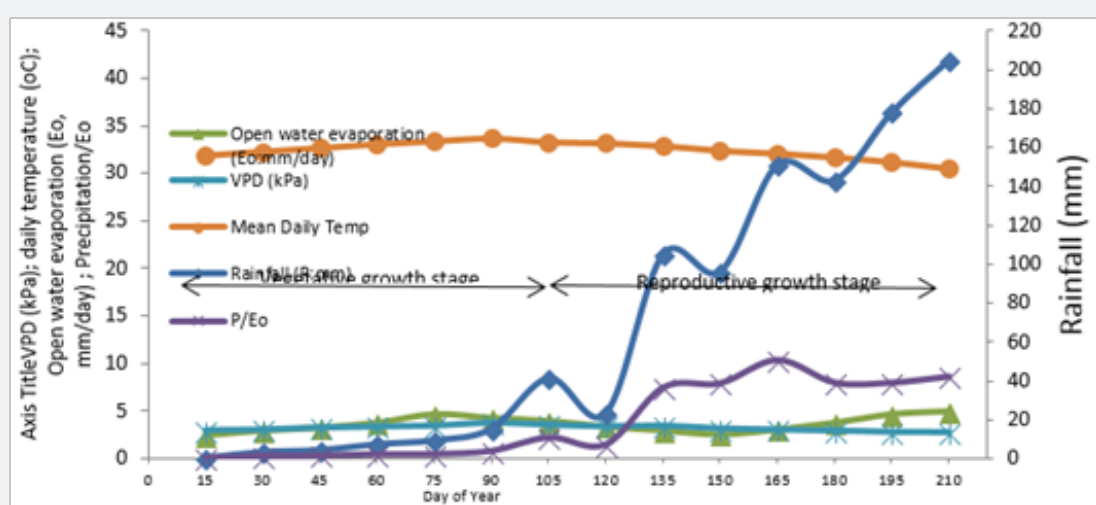

Figure 1: Important weather variables during early rainy season.

\section{Results}

The weather conditions of the early and late rainy seasonin the study area

Some meteorological variables during the growth of cowpea in the respective early and late rainy cropping seasons of 2015 and 2016 are presented in Figure 1,2. There were dry spells between rainfall episodes particularly in the early part of the early and the latter part of the late rainy seasons.Compared with the early rainy season, the late season is characterized by high climatic demand (high vapour pressure deficit: vpd), crop water demand (open water evaporation: Eo) and temperatures in addition to low and scanty rainfall particularly towards the close of the growing season which coincided with reproductive growth phase of cowpea. The earlier part of the rainy and later part of the late season was characterized by concurrent stresses of high intensities of soil moisture and vapour pressure deficits (atmospheric demand). The rainy season is characterized by increasing trends in rainfall amounts and open water evaporation (Eo) and atmospheric demand during cowpea vegetative and the reproductive growth phases (Figure 1).However, the earlier part of the rainy season which coincided with the establishment phase is characterized by low rainfall amount and high temperatures. However, during the late rainy season, environmental conditions were the opposite of the early rainy season; there were decreases in rainfall amounts and high temperatures, vapor pressure deficits and open water evaporation (Figure 2). However, concurrent and increasing intensities of stress factors of highevaporative demand and temperatures characterized the later part of the late season (the reproductive phase of cowpea).

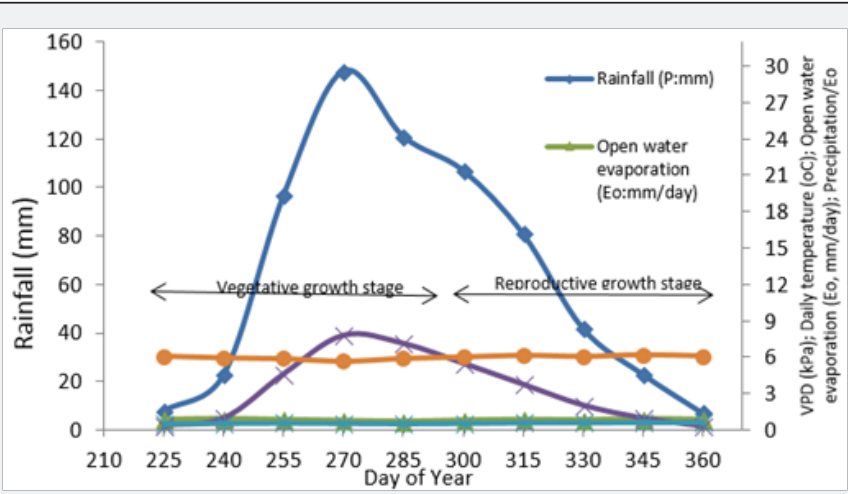

Figure 2: Important weather variables during late rainy season. 


\section{Growth and yield of cowpea varieties sown as early- and late-rainy season crop in Akure and Ado Ekiti locations}

The growth yield and yield components of cowpea varieties planted as early rainy season crop in Akure (2013 and 2014 experiments)is presented in Table $2 \& 3$. The results show that IT96D-610 had the longest vine at 7 weeks after planting (WAP) whilesignificantly higher number of leaves andbranches were obtained forOloyin Brown (113.56, 7.89). Oloyin brown had significantly longer vines at 7 WAP $(129.7 \mathrm{~cm})$ compared with other cowpea varieties. The number of leaves was highest for IT97K-568-18, the value was significantly different from those ofIT98K- 573-2-1. The variety IT98K- 573-2-1 had the highest numbers of branches at 7 weeks after planting. Oloyin Brown had the highest numbers of nodules and weights ofshoot and peduncles among the cowpea varieties and IT98K-573-2-1 attained days to $50 \%$ flowering later compared with other varieties. In terms of yield characters, IT96D-610 had the highest number of pods per plant (26.0) but the lowest number of seeds per pod (9.11). The highest number of seeds per pod and seed yield per plant $(83.3 \mathrm{~kg} / \mathrm{ha})$ were recorded forlT98K-573-2-1 (14.33) despite its lower number ofpods compared with IT96D-610. Table 4 shows that IT98K-573-2-1 had the highest number pods(20.38), longest pods $(15.57 \mathrm{~cm})$ and pod weight $(73.59 \mathrm{~g})$ while Oloyin Brown was better in seed weight/pod $(19.66 \mathrm{~g})$ and seed yield $(60.67 \mathrm{~kg} / \mathrm{ha})$. Lowest shoot weight (111.4g), numbers of nodules (7.89) and peduncles (10.3), pod length $(12.9 \mathrm{~cm})$ were however obtained for IT98K-205-8.Ife Brown gave the lowest number of days to attain $50 \%$ flowering (45 days) while Oloyin Brown gave the highest (52 days). The vine lengths were higher in IT97K-568-18 and is significantly different among the tested cowpea varieties $(105.10 \mathrm{~cm})$ Similar result was obtained for number of leaves and number of branches with IT97K-568-18 as it gave the highest numbers of leaves and branches at 7 weeks after planting $(109.11,7.90)$ respectively.
Oloyin Brown had the highest number of nodules (8.2), highest number of peduncles (7.44), and highest pod weight $(55.4 \mathrm{~g})$ among the tested varieties.

Cowpea variety, IT98K-573-2-1 gave the highest shoot biomass and is highly significant among all tested varieties (166.7g). The number of days to attain 50\% flowering was consistently earlier for Ife Brown across the trials (45 days) while IT97K-568-18 and Oloyin Brown gave consistently longer days ( 60 and 55 days). Flowering commenced early for Ife Brown while IT97K-568-18 gave the longestnumber of days to attain $50 \%$ flowering. However, IT98K-573-2-1 was better in seed production, among the varieties, it was the best in terms of the total number of seeds per pod (14.77) and seed yield $(45.2 \mathrm{~kg} /$ ha). The number of pods per plant was highest in IT98K-205-8 (17.4) and IT96D-610 (16.7) but seed yield was lowest. The days to attain $50 \%$ floweing was shortest in Ife Brown in the late rainy season (38days) but longer (47 days) in IT97K-568-18. Among cowpea varieties tested, IT98K-573-2-1 produced the highest number of seeds per pod (18.9), and seed yield (107.9kg/ha). The variety Oloyin brown of the early rainy season produced the highest number of pods (41.3) while the lowest seed yield was recorded with IT98K-205-8 (23.3kg/ha). Table 4 shows that IT97K-568-18 gave the highest number of nodules (13.6) and highest number of days to attain 50\% flowering (48) while IT98K-573-2-1 was better in total number of pods per plant (27.5), total pod weight (53.58g), number of seeds per pod (14.77), seed weight $(22.36 \mathrm{~g})$ and seed yield $(90.8 \mathrm{t} / \mathrm{ha})$. The lowest seed yield was recorded with IT98K-205-8 $(25.4 \mathrm{~kg} /$ ha). The number of pods per plant is one the most important component in determining yield in several legume crops generally, variation in the number of pods per plant depends on the type of legumes species.In the late season, the cultivars of Oloyin Brown, IT98K-573-2-1 and IT97K-568-18 produced heaviest shoot weight, number of pods per plant, number of seeds per pod and pod weight (Tables 2-4).

Table 2: Performance of cowpea planted as early and late season crop (2013 experiment, Akure), Means along the column bearing same letters are not significantly different DMRT $(p<0.05)$

\begin{tabular}{|c|c|c|c|c|c|c|c|c|c|c|c|c|c|c|}
\hline Varieties & $\begin{array}{c}\text { Number } \\
\text { of } \\
\text { leaves } \\
\text { (7WAP) }\end{array}$ & $\begin{array}{c}\text { Number of } \\
\text { branches } \\
\text { (7WAP) }\end{array}$ & $\begin{array}{c}\text { Vine } \\
\text { Length } \\
\text { (cm) } \\
\text { (7WAP) }\end{array}$ & $\begin{array}{c}\text { Number } \\
\text { of } \\
\text { nodules }\end{array}$ & $\begin{array}{c}\text { Shoot } \\
\text { biomass } \\
\text { (g) }\end{array}$ & $\begin{array}{l}\text { Number of } \\
\text { peduncles }\end{array}$ & $\begin{array}{c}\text { Days } \\
\text { to } 50 \% \\
\text { flowering }\end{array}$ & $\begin{array}{l}\text { Number } \\
\text { of pods }\end{array}$ & Pod (g) & $\begin{array}{c}\text { Pod } \\
\text { Length } \\
\text { (cm) }\end{array}$ & $\begin{array}{l}\text { Number } \\
\text { of seeds }\end{array}$ & $\begin{array}{c}100 \\
\text { Seed } \\
\text { weight } \\
\text { (g) }\end{array}$ & $\begin{array}{c}\text { Seed } \\
\text { Yield } \\
\text { (kg/ } \\
\text { ha) }\end{array}$ & $\begin{array}{c}\text { Harvest } \\
\text { index }\end{array}$ \\
\hline \multicolumn{15}{|c|}{ Early Season Crop } \\
\hline IT98K-205-8 & $65.3 b c$ & $4.9 \mathrm{a}$ & $98.20 \mathrm{~b}$ & $7.89 a$ & $111.41 b$ & $10.3 b$ & $50.0 \mathrm{a}$ & $15.33 a$ & $53.88 \mathrm{~b}$ & $12.9 \mathrm{a}$ & $11.22 \mathrm{ab}$ & $15.4 \mathrm{a}$ & $26.48 \mathrm{~d}$ & $0.23 a$ \\
\hline Ife brown & $99.7 \mathrm{ab}$ & $5.5 a$ & $82.6 \mathrm{bc}$ & $8.67 a$ & $125.4 \mathrm{~b}$ & $16.0 \mathrm{~b}$ & $45.0 \mathrm{~b}$ & $16.11 \mathrm{a}$ & $71.56 a$ & $13.73 a$ & 12.11ab & 14.39ab & $28.07 d$ & $0.22 \mathrm{a}$ \\
\hline IT96D-610 & $107 a b$ & $6.6 a$ & 106.6ab & $12.1 \mathrm{a}$ & $112.5 b$ & $16.8 b$ & $52.0 \mathrm{a}$ & $18.39 a$ & $38.18 \mathrm{c}$ & $15.70 \mathrm{a}$ & $10.22 \mathrm{ab}$ & $17.79 a$ & $33.4 \mathrm{c}$ & $0.30 \mathrm{a}$ \\
\hline IT98K-573-2-1 & $77.1 \mathrm{~b}$ & $8.6 a$ & $102.9 \mathrm{ab}$ & $12.9 \mathrm{a}$ & $178.2 \mathrm{ab}$ & $18.7 \mathrm{~b}$ & $50.0 \mathrm{a}$ & $20.38 a$ & $73.59 a$ & $15.57 a$ & 11.67ab & $17.22 \mathrm{a}$ & $42.14 b$ & $0.24 a$ \\
\hline Oloyin brown & $102 \mathrm{ab}$ & $7.9 \mathrm{a}$ & $129.70 a$ & $12.4 \mathrm{a}$ & $221.6 a$ & $16.9 \mathrm{~b}$ & $52.4 \mathrm{a}$ & $19.29 a$ & $48.64 \mathrm{~b}$ & $15.03 a$ & $16.00 \mathrm{a}$ & $19.66 a$ & $60.67 a$ & $0.27 a$ \\
\hline IT97K-568-18 & $135 a$ & $7.5 \mathrm{a}$ & $85.14 b c$ & $10.9 a$ & $125.9 \mathrm{~b}$ & $28.1 \mathrm{a}$ & $50.0 \mathrm{a}$ & $13.78 \mathrm{a}$ & $23.29 \mathrm{~d}$ & $14.78 \mathrm{a}$ & $11.33 \mathrm{ab}$ & $13.42 \mathrm{ab}$ & $20.95 d$ & $0.17 \mathrm{a}$ \\
\hline Varieties & $\begin{array}{c}\text { Number } \\
\text { of } \\
\text { leaves } \\
\text { (7WAP) }\end{array}$ & $\begin{array}{c}\text { Number of } \\
\text { branches } \\
\text { (7WAP) }\end{array}$ & $\begin{array}{c}\text { Vine } \\
\text { Length } \\
\text { (cm) } \\
\text { (7WAP) }\end{array}$ & $\begin{array}{c}\text { Number } \\
\text { of } \\
\text { nodules }\end{array}$ & $\begin{array}{c}\text { Shoot } \\
\text { biomass } \\
\text { (g) }\end{array}$ & $\begin{array}{l}\text { Number of } \\
\text { peduncles }\end{array}$ & $\begin{array}{c}\text { Days } \\
\text { to } 50 \% \\
\text { flowering }\end{array}$ & $\begin{array}{l}\text { Number } \\
\text { of pods }\end{array}$ & $\begin{array}{c}\text { Pod } \\
\text { Weight } \\
\text { (g) }\end{array}$ & $\begin{array}{c}\text { Pod } \\
\text { Length } \\
\text { (cm) }\end{array}$ & $\begin{array}{l}\text { Number } \\
\text { of seeds }\end{array}$ & $\begin{array}{c}100 \\
\text { Seed } \\
\text { weight } \\
\text { (g) }\end{array}$ & $\begin{array}{c}\text { Seed } \\
\text { Yield } \\
\text { (kg/ } \\
\text { ha) }\end{array}$ & $\begin{array}{c}\text { Harvest } \\
\text { index }\end{array}$ \\
\hline
\end{tabular}


JOJ Horticulture \& Arboriculture

\begin{tabular}{|c|c|c|c|c|c|c|c|c|c|c|c|c|c|c|}
\hline IT98K-205-8 & $59.6 \mathrm{c}$ & $5.9 \mathrm{ab}$ & $67.0 \mathrm{bc}$ & $12.6 \mathrm{a}$ & $68.97 \mathrm{~b}$ & $7.1 \mathrm{a}$ & $40 \mathrm{ab}$ & $20.5 a$ & $23.45 d$ & $23.7 \mathrm{a}$ & $12.11 \mathrm{a}$ & $14.74 \mathrm{ab}$ & $25.4 \mathrm{c}$ & $0.46 \mathrm{a}$ \\
\hline Ife brown & $92.2 \mathrm{ab}$ & $6.5 \mathrm{ab}$ & $78.83 c$ & $11.0 \mathrm{a}$ & $85.4 \mathrm{ab}$ & $6.0 \mathrm{a}$ & $40 \mathrm{ab}$ & $23.9 a$ & $31.8 c$ & $19.9 \mathrm{ab}$ & $11.11 \mathrm{a}$ & $13.15 \mathrm{ab}$ & $34.8 \mathrm{bc}$ & $0.36 a$ \\
\hline IT96D-610 & $72.6 \mathrm{bc}$ & $7.5 \mathrm{ab}$ & $96.63 \mathrm{~b}$ & $11.5 \mathrm{a}$ & $66.45 b$ & $5.1 \mathrm{a}$ & $48 a$ & $18.9 \mathrm{~b}$ & $42.73 b$ & $23.1 \mathrm{a}$ & $12.12 \mathrm{a}$ & $17.40 \mathrm{ab}$ & $39.9 \mathrm{bc}$ & $0.36 a$ \\
\hline IT98K-573-2-1 & $61.2 \mathrm{bc}$ & $8.9 \mathrm{ab}$ & $109.9 \mathrm{a}$ & $14.9 \mathrm{a}$ & $92.8 \mathrm{ab}$ & $8.6 a$ & $43 a b$ & $27.5 \mathrm{a}$ & $53.58 \mathrm{a}$ & $25.6 \mathrm{a}$ & $14.77 \mathrm{a}$ & $22.36 a$ & $90.8 \mathrm{a}$ & $0.97 a$ \\
\hline Oloyin brown & 95.8ab & $11.5 \mathrm{a}$ & $113.7 \mathrm{a}$ & $10.9 \mathrm{~b}$ & $110.5 a$ & $9.4 \mathrm{a}$ & 46.a & $24.5 a$ & $48.32 \mathrm{ab}$ & $24.5 \mathrm{a}$ & $12.88 \mathrm{a}$ & $14.11 \mathrm{ab}$ & $44.5 \mathrm{~b}$ & $0.66 \mathrm{a}$ \\
\hline IT97K-568-18 & $101.1 \mathrm{a}$ & $13.9 a$ & $115.1 \mathrm{a}$ & $13.6 \mathrm{a}$ & $97.27 \mathrm{ab}$ & $6.0 \mathrm{a}$ & 48.a & $17.5 \mathrm{ab}$ & $38.55 b$ & $18.9 \mathrm{ab}$ & $10.66 a$ & $13.65 \mathrm{ab}$ & $36.5 b c$ & $0.26 a$ \\
\hline
\end{tabular}

Table 3: Performance of cowpea planted as early and late season crop (2014 early and late rainy season experiments, Akure), (WAP) Weeks after planting) Means along the column bearing same letters are not significantly different DMRT $(p<0.05)$.

\begin{tabular}{|c|c|c|c|c|c|c|c|c|c|c|c|c|c|c|}
\hline Varieties & $\begin{array}{c}\text { Number } \\
\text { of leaves } \\
\text { (7WAP) }\end{array}$ & $\begin{array}{c}\text { Number } \\
\text { of } \\
\text { branches } \\
\text { (7WAP) }\end{array}$ & $\begin{array}{c}\text { Vine } \\
\text { Length } \\
\text { (7WAP) }\end{array}$ & $\begin{array}{c}\text { Number } \\
\text { of } \\
\text { nodules }\end{array}$ & $\begin{array}{c}\text { Shoot } \\
\text { biomass } \\
\text { (g) }\end{array}$ & $\begin{array}{c}\text { Number } \\
\text { of } \\
\text { peduncles }\end{array}$ & $\begin{array}{c}\text { Days } \\
\text { to } 50 \% \\
\text { Flowering }\end{array}$ & $\begin{array}{c}\text { Number } \\
\text { of pods }\end{array}$ & $\begin{array}{c}\text { Pod } \\
\text { Weight } \\
\text { (g) }\end{array}$ & $\begin{array}{c}\text { Pod } \\
\text { Length } \\
(\mathrm{cm})\end{array}$ & $\begin{array}{l}\text { Number } \\
\text { of seeds }\end{array}$ & $\begin{array}{c}100 \text { Seed } \\
\text { weight } \\
\text { (g) }\end{array}$ & $\begin{array}{c}\text { Seed } \\
\text { Yield } \\
\text { (kg/ha) }\end{array}$ & $\begin{array}{c}\text { Harvest } \\
\text { index }\end{array}$ \\
\hline \multicolumn{15}{|c|}{ Early Season Crop } \\
\hline IT98K-205-8 & $69.6 c$ & $7.4 \mathrm{a}$ & $104 \mathrm{a}$ & $13 a$ & $78.97 \mathrm{~b}$ & $6.11 \mathrm{a}$ & $45 b$ & $17.4 \mathrm{a}$ & $23.6 \mathrm{bc}$ & $11.5 a$ & $12.11 \mathrm{a}$ & $14.74 \mathrm{ab}$ & $30.9 b c$ & $0.39 a$ \\
\hline Ife brown & $102 \mathrm{a}$ & $6.7 \mathrm{a}$ & $78.8 \mathrm{bc}$ & $3.7 \mathrm{ab}$ & $95.38 \mathrm{ab}$ & $4.00 \mathrm{a}$ & $40 \mathrm{bc}$ & $14.0 \mathrm{ab}$ & $24.7 \mathrm{bc}$ & $9.8 \mathrm{a}$ & $11.11 \mathrm{a}$ & $13.15 \mathrm{ab}$ & $20.5 \mathrm{~d}$ & $0.21 \mathrm{a}$ \\
\hline IT96D-610 & $92.6 \mathrm{ab}$ & $5.9 \mathrm{a}$ & $86.6 \mathrm{~b}$ & $5.2 \mathrm{ab}$ & $110.5 a$ & $3.12 \mathrm{a}$ & 48ab & $16.7 \mathrm{ab}$ & $33.5 b$ & $10.5 a$ & $12.12 \mathrm{a}$ & $17.40 \mathrm{a}$ & $35.2 \mathrm{ab}$ & $0.32 \mathrm{a}$ \\
\hline IT98K-573-2-1 & $71.2 \mathrm{~b}$ & $7.6 \mathrm{a}$ & $89.9 b$ & $4.7 \mathrm{ab}$ & 92.83ab & $6.55 a$ & $45 b$ & $13.7 \mathrm{ab}$ & $47.2 \mathrm{ab}$ & $6.9 \mathrm{ab}$ & $14.77 \mathrm{a}$ & $22.36 a$ & $45.2 \mathrm{a}$ & $0.48 \mathrm{a}$ \\
\hline Oloyin brown & $105.8 \mathrm{a}$ & $7.5 \mathrm{a}$ & $104 a$ & $8.2 \mathrm{ab}$ & $66.45 \mathrm{bc}$ & $7.44 a$ & $50 \mathrm{ab}$ & $10.3 \mathrm{ab}$ & $55.4 \mathrm{a}$ & $7.9 \mathrm{ab}$ & $12.88 \mathrm{a}$ & $14.11 \mathrm{ab}$ & $18.72 \mathrm{c}$ & $0.28 \mathrm{a}$ \\
\hline IT97K-568-18 & $109.1 \mathrm{a}$ & $7.9 \mathrm{a}$ & $105 a$ & $5.8 \mathrm{ab}$ & $100.5 a$ & $4.00 \mathrm{a}$ & $55 a$ & $13.0 \mathrm{ab}$ & $34.1 \mathrm{~b}$ & $4.0 \mathrm{ab}$ & $10.66 a$ & $13.65 \mathrm{ab}$ & $18.9 \mathrm{c}$ & $0.18 \mathrm{a}$ \\
\hline Varieties & $\begin{array}{l}\text { Number } \\
\text { of leaves } \\
\text { (7WAP) }\end{array}$ & $\begin{array}{c}\text { Number } \\
\text { of } \\
\text { branches } \\
\text { (7WAP) }\end{array}$ & $\begin{array}{c}\text { Vine } \\
\text { Length } \\
\text { (cm) } \\
\text { (7WAP) }\end{array}$ & $\begin{array}{c}\text { Number } \\
\text { of } \\
\text { nodules }\end{array}$ & $\begin{array}{c}\text { Shoot } \\
\text { biomass } \\
\text { (g) }\end{array}$ & $\begin{array}{c}\text { Number } \\
\text { of } \\
\text { peduncles }\end{array}$ & $\begin{array}{c}\text { Days } \\
\text { to } 50 \% \\
\text { Flowering }\end{array}$ & $\begin{array}{l}\text { Number } \\
\text { of pods }\end{array}$ & $\begin{array}{c}\text { Pod } \\
\text { Weight } \\
\text { (g) }\end{array}$ & $\begin{array}{c}\text { Pod } \\
\text { Length } \\
\text { (cm) }\end{array}$ & $\begin{array}{l}\text { Number } \\
\text { of seeds }\end{array}$ & $\begin{array}{c}100 \text { Seed } \\
\text { weight } \\
\text { (g) }\end{array}$ & $\begin{array}{c}\text { Seed } \\
\text { Yield } \\
\text { (kg/ha) }\end{array}$ & $\begin{array}{c}\text { Harvest } \\
\text { index }\end{array}$ \\
\hline \multicolumn{15}{|c|}{ Late season Crop } \\
\hline IT98K-205-8 & $93.1 \mathrm{~b}$ & $5 \mathrm{ab}$ & $85.7 \mathrm{ab}$ & $2.3 \mathrm{a}$ & $107 \mathrm{~b}$ & $16.3 \mathrm{ab}$ & $45 a$ & $23.5 b$ & $69.5 b$ & $14.9 \mathrm{ab}$ & $10 \mathrm{a}$ & $15.9 \mathrm{ab}$ & $36.9 c$ & $0.34 \mathrm{a}$ \\
\hline Ife brown & $81.3 \mathrm{bc}$ & $6 \mathrm{ab}$ & $81.2 \mathrm{ab}$ & $3.5 \mathrm{a}$ & $95 \mathrm{bc}$ & $15.8 \mathrm{ab}$ & $40 \mathrm{ab}$ & $24.0 \mathrm{~b}$ & $79.3 a$ & $24.5 \mathrm{a}$ & $11 \mathrm{a}$ & $15.7 \mathrm{ab}$ & $41.1 \mathrm{~b}$ & $0.44 \mathrm{a}$ \\
\hline IT96D-610 & $84.1 \mathrm{bc}$ & $10 \mathrm{a}$ & $77.4 \mathrm{bc}$ & $2.9 \mathrm{a}$ & $85 c$ & $18.2 \mathrm{ab}$ & $35 b$ & $19.0 \mathrm{~b}$ & $89.0 \mathrm{a}$ & $15.9 \mathrm{ab}$ & $9.0 \mathrm{a}$ & $15.2 \mathrm{ab}$ & $34.4 \mathrm{c}$ & $0.41 \mathrm{a}$ \\
\hline IT98K-573-2-1 & $154 a$ & $12 \mathrm{a}$ & $82.4 \mathrm{ab}$ & $5.1 \mathrm{a}$ & $102 \mathrm{~b}$ & $23.0 \mathrm{a}$ & $35 \mathrm{~b}$ & $26.0 \mathrm{~b}$ & $32.5 \mathrm{~d}$ & $22.5 a$ & $12 \mathrm{a}$ & $19.4 \mathrm{a}$ & $46.6 \mathrm{~b}$ & $0.45 a$ \\
\hline Oloyin brown & $122 \mathrm{ab}$ & $9 a$ & $97.2 \mathrm{a}$ & $6.7 \mathrm{a}$ & $165 a$ & $19.3 \mathrm{ab}$ & $41 \mathrm{a}$ & $36.5 \mathrm{a}$ & $59.5 \mathrm{c}$ & $25.6 \mathrm{a}$ & $13 a$ & $20.2 \mathrm{a}$ & $98.7 \mathrm{a}$ & $0.59 a$ \\
\hline IT97K-568-18 & $71.8 \mathrm{c}$ & $7 \mathrm{a}$ & $99.8 \mathrm{a}$ & $4.9 \mathrm{a}$ & $104 \mathrm{~b}$ & $23.4 \mathrm{a}$ & $43 a$ & $21.5 b$ & $76.4 \mathrm{a}$ & $16.9 \mathrm{ab}$ & $12 \mathrm{a}$ & $18.5 \mathrm{a}$ & $45.3 b$ & $0.45 a$ \\
\hline
\end{tabular}

Table 4: Performance of cowpea planted as early and late season crop (2015 experiment, Ado-Ekiti), (WAP) Weeks after planting) Means along the column bearing same letters are not significantly different DMRT $(p<0.05)$.

\begin{tabular}{|c|c|c|c|c|c|c|c|c|c|c|c|c|c|c|}
\hline Varieties & $\begin{array}{c}\text { Number } \\
\text { of leaves } \\
\text { (7WAP) }\end{array}$ & $\begin{array}{c}\text { Number of } \\
\text { branches } \\
\text { (7WAP) }\end{array}$ & $\begin{array}{c}\text { Vine } \\
\text { Length } \\
\text { (cm) } \\
\text { (7WAP) }\end{array}$ & $\begin{array}{c}\text { Number } \\
\text { of } \\
\text { nodules }\end{array}$ & $\begin{array}{c}\text { Shoot } \\
\text { biomass } \\
\text { (g) }\end{array}$ & $\begin{array}{l}\text { Number of } \\
\text { peduncles }\end{array}$ & $\begin{array}{c}\text { Days to } \\
50 \%\end{array}$ & $\begin{array}{c}\text { Number } \\
\text { of pods }\end{array}$ & $\begin{array}{c}\text { Pod } \\
\text { Weight } \\
\text { (g) }\end{array}$ & $\begin{array}{c}\text { Pod } \\
\text { Length } \\
\text { (cm) }\end{array}$ & $\begin{array}{l}\text { Number } \\
\text { of seeds }\end{array}$ & $\begin{array}{c}100 \text { Seed } \\
\text { weight } \\
\text { (g) }\end{array}$ & $\begin{array}{l}\text { Seed } \\
\text { Yield } \\
\text { (kg/ } \\
\text { ha) }\end{array}$ & $\begin{array}{c}\text { Harvest } \\
\text { index }\end{array}$ \\
\hline \multicolumn{15}{|c|}{ Early Season } \\
\hline IT98K-205-8 & $103 a$ & $6.5 \mathrm{a}$ & $112 \mathrm{ab}$ & $2 \mathrm{c}$ & $99.4 \mathrm{bc}$ & $6.0 \mathrm{~cd}$ & $46 \mathrm{c}$ & $12.0 \mathrm{~d}$ & $23.7 \mathrm{~d}$ & $22.4 a$ & $13.0 \mathrm{a}$ & $16.9 \mathrm{a}$ & $23.3 \mathrm{~d}$ & $0.23 \mathrm{a}$ \\
\hline IFE BROWN & $89.3 \mathrm{bc}$ & $5.9 a$ & $97 b$ & $6 b$ & $76.6 \mathrm{c}$ & $6.6 \mathrm{~cd}$ & $45 \mathrm{~cd}$ & $23.4 \mathrm{c}$ & $75.0 \mathrm{~b}$ & $13.7 \mathrm{~b}$ & $8.6 \mathrm{~d}$ & $20.5 a$ & $41.3 c$ & $0.54 \mathrm{a}$ \\
\hline IT96D-610 & $87.2 \mathrm{bc}$ & $6.9 a$ & $65 c$ & $11 \mathrm{a}$ & $110 \mathrm{bc}$ & $9.9 \mathrm{ab}$ & $50 \mathrm{~b}$ & $25.6 \mathrm{c}$ & $61.8 \mathrm{c}$ & $14.5 b$ & $15.9 a$ & $22.4 \mathrm{a}$ & $91.2 \mathrm{ab}$ & $0.83 a$ \\
\hline IT98K-573-2-1 & $81.4 \mathrm{bc}$ & $8.8 \mathrm{a}$ & $92 b$ & $8.1 \mathrm{a}$ & $167 a$ & $11.8 \mathrm{a}$ & $50 \mathrm{c}$ & $29.9 c$ & 82.1ab & $17.6 \mathrm{~b}$ & $18.9 a$ & $19.1 \mathrm{a}$ & $108 \mathrm{a}$ & $0.64 \mathrm{a}$ \\
\hline $\begin{array}{l}\text { OLOYIN } \\
\text { BROWN }\end{array}$ & $94.5 \mathrm{ab}$ & $7.5 \mathrm{a}$ & $134 \mathrm{a}$ & $10 \mathrm{a}$ & 148ab & $8.4 b c$ & $55 a$ & $41.3 a$ & $88.6 a$ & $19.7 \mathrm{a}$ & $12.6 \mathrm{a}$ & $18.3 \mathrm{~b}$ & $95.2 \mathrm{ab}$ & $0.55 a$ \\
\hline IT97K-568-18 & $78.0 \mathrm{~d}$ & $5.7 \mathrm{a}$ & $108 \mathrm{ab}$ & $13 a$ & $138 a b$ & $5.2 \mathrm{~d}$ & $61 \mathrm{~cd}$ & $36.8 \mathrm{~b}$ & $57.5 \mathrm{c}$ & $15.5 b$ & $11.6 a$ & $15.2 \mathrm{a}$ & $64.6 \mathrm{~b}$ & $0.64 \mathrm{a}$ \\
\hline Varieties & $\begin{array}{c}\text { Number } \\
\text { of leaves } \\
\text { (7WAP) }\end{array}$ & Number & $\begin{array}{l}\text { Vine } \\
\text { Length } \\
\text { (cm) } \\
\text { (7WAP) }\end{array}$ & $\begin{array}{c}\text { Number } \\
\text { of } \\
\text { nodules }\end{array}$ & $\begin{array}{c}\text { Shoot } \\
\text { biomass } \\
\text { (g) }\end{array}$ & $\begin{array}{l}\text { Number of } \\
\text { peduncles }\end{array}$ & $\begin{array}{c}\text { Days } \\
\text { to } 50 \% \\
\text { Flowering }\end{array}$ & $\begin{array}{c}\text { Number } \\
\text { of pods }\end{array}$ & $\begin{array}{c}\text { Pod } \\
\text { Weight } \\
\text { (g) }\end{array}$ & $\begin{array}{c}\text { Pod } \\
\text { Length } \\
\text { (cm) }\end{array}$ & $\begin{array}{l}\text { Number } \\
\text { of seeds }\end{array}$ & $\begin{array}{c}100 \text { Seed } \\
\text { weight } \\
\text { (g) }\end{array}$ & $\begin{array}{l}\text { Seed } \\
\text { Yield } \\
\text { (kg/ } \\
\text { ha) }\end{array}$ & $\begin{array}{c}\text { Harvest } \\
\text { index }\end{array}$ \\
\hline \multicolumn{15}{|c|}{ Late season } \\
\hline IT98K-205-8 & $81.3 b$ & $4.9 b$ & $77.8 \mathrm{~b}$ & $6.7 \mathrm{a}$ & $103 \mathrm{c}$ & $18 \mathrm{a}$ & $45 a$ & $14.9 \mathrm{c}$ & $86.3 a$ & $15.6 \mathrm{a}$ & $11.10 \mathrm{a}$ & $19.10 \mathrm{a}$ & $31.8 \mathrm{c}$ & $0.31 \mathrm{c}$ \\
\hline Ife brown & $57.0 \mathrm{c}$ & $5.5 b$ & $46.3 c$ & $4.9 \mathrm{ab}$ & $88.3 \mathrm{e}$ & $5 c$ & $41 \mathrm{a}$ & $21.3 a$ & $59.5 \mathrm{~d}$ & $11.8 \mathrm{~b}$ & $10.20 \mathrm{a}$ & $17.00 \mathrm{a}$ & $36.9 c$ & $0.42 \mathrm{a}$ \\
\hline IT96D-610 & $96.3 \mathrm{ab}$ & $6.5 b$ & $94.8 \mathrm{ab}$ & $3.6 \mathrm{ab}$ & $94.5 \mathrm{~d}$ & $13 \mathrm{ab}$ & $36 c$ & $18.3 \mathrm{~b}$ & $29.9 f$ & $13.7 \mathrm{a}$ & $11.30 \mathrm{a}$ & $16.10 \mathrm{a}$ & $33.3 c$ & $0.35 c$ \\
\hline
\end{tabular}


JOJ Horticulture \& Arboriculture

\begin{tabular}{|c|c|c|c|c|c|c|c|c|c|c|c|c|c|c|}
\hline IT98K-573-2-1 & $67.9 \mathrm{bc}$ & $8.5 a$ & $77.2 \mathrm{~b}$ & $4.5 \mathrm{ab}$ & $83.9 \mathrm{e}$ & $19 a$ & $46 b$ & $24.0 \mathrm{a}$ & $44.5 \mathrm{e}$ & $12.5 b$ & $13.70 \mathrm{a}$ & $18.30 \mathrm{a}$ & $60.2 \mathrm{a}$ & $0.72 \mathrm{a}$ \\
\hline Oloyin brown & $114 a$ & $9.7 \mathrm{a}$ & $79.4 b$ & $5.0 \mathrm{a}$ & $191 \mathrm{a}$ & $16 a$ & $46 b$ & $22.9 a$ & $75.4 b$ & $16.9 \mathrm{a}$ & $13.80 \mathrm{a}$ & $19.40 \mathrm{a}$ & $60.9 a$ & $0.32 \mathrm{c}$ \\
\hline IT97K-568-18 & $66.9 \mathrm{~b}$ & $4.5 \mathrm{~b}$ & $105 a$ & $6.8 \mathrm{a}$ & $160 \mathrm{~b}$ & $10 \mathrm{bc}$ & $51 \mathrm{a}$ & $23.1 \mathrm{a}$ & $69.5 c$ & $14.5 \mathrm{a}$ & $9.90 \mathrm{~b}$ & $19.02 a$ & $43.5 b$ & $0.27 \mathrm{~d}$ \\
\hline
\end{tabular}

Table 5 presents the summary of growth and yield characters of cowpea varieties early and late season crops and acrossAkure and ado Ekiti locations. The results show that Ife Brown gave consistently lower number (45 days) of days to attain $50 \%$ flowering among the cowpea varieties in the early rainy season while Oloyin Brown and IT97K-568-18 had longer days to attain $50 \%$ flowering (55 days). Shoot weight was highest for Oloyin Brown (132.5g) across the rainy season experiments. Oloyin Brown on the average was better in number of seeds per pod (14.1) while IT98K-573-2-1 was better in seed weight (21.9g), pod weight $(55.0 \mathrm{~g})$ and seed yield $(56.9 \mathrm{~g})$. The total seed weight across season was highest in IT98K-573-2-1 (1,246.9g) while the lowest seed yield was Ife brown with (27.4g). Though, IT96D-610 had highest number of pods on the average (20.4). The number of pods per plant an important component in determining seed yield in several legume crops.Differences in the number of pods per plant were found among cowpea varieties evaluated in this study. Under the late season growing weather conditions, the cultivars of Oloyin Brown, IT98K-573-2-1 and IT96D-610 were better in terms of shoot weight, number of pods per plant, number of seeds per pod and pod weight(Table 4.9.1). In general, values of shoot biomass were batter in Oloyin brown in the late rainy season among all tested cowpea varieties(115.6g).Number of pods were higher in Oloyin brown (31.0) and total pod weight were higher in IT96D-610 (65.9g). In terms of total number of seeds per pod and average seed yield, Oloyin brown gave the highest number (13.5g) and (72.0g). IT98K-753-2-1 however gave the highest seed weight $(1,423 \mathrm{~g})$ among tested varieties in the late rainy season in Akure.

Table 5: Cowpea performance as early and late season crops across Akure and Ado Ekiti locations.

\begin{tabular}{|c|c|c|c|c|c|c|c|c|c|c|c|c|c|c|}
\hline Seasons & $\begin{array}{c}\text { Number } \\
\text { of } \\
\text { leaves } \\
\text { (7WAP) }\end{array}$ & $\begin{array}{c}\text { Number } \\
\text { of } \\
\text { branches } \\
\text { (7WAP) }\end{array}$ & $\begin{array}{c}\text { Vine } \\
\text { Length } \\
\text { (cm) }\end{array}$ & $\begin{array}{c}\text { Number } \\
\text { of } \\
\text { nodules }\end{array}$ & $\begin{array}{c}\text { Shoot } \\
\text { biomass } \\
\text { (g) }\end{array}$ & $\begin{array}{l}\text { Number of } \\
\text { peduncles }\end{array}$ & $\begin{array}{c}\text { Days } \\
\text { to } 50 \% \\
\text { Flowering }\end{array}$ & $\begin{array}{l}\text { Number } \\
\text { of pods }\end{array}$ & $\begin{array}{c}\text { Pod } \\
\text { Weight } \\
\text { (g) }\end{array}$ & $\begin{array}{c}\text { Pod } \\
\text { Length } \\
\text { (cm) }\end{array}$ & $\begin{array}{l}\text { Number } \\
\text { of seeds }\end{array}$ & $\begin{array}{c}100 \text { Seed } \\
\text { weight } \\
\text { (g) }\end{array}$ & $\begin{array}{c}\text { Seed } \\
\text { Yield } \\
\text { (kg/ha) }\end{array}$ & $\begin{array}{c}\text { Harvest } \\
\text { index }\end{array}$ \\
\hline $\begin{array}{c}\text { Early } \\
\text { season }\end{array}$ & $93 a$ & $7 a$ & $100 \mathrm{a}$ & $9 a$ & $113 a$ & $9 b$ & $49 a$ & $20 a$ & $50 \mathrm{~b}$ & $13 b$ & $13 a$ & $17 a$ & $45 a$ & $0.37 \mathrm{a}$ \\
\hline $\begin{array}{c}\text { Late } \\
\text { season }\end{array}$ & $87 b$ & $8 a$ & $88 b$ & $7 a$ & $106 b$ & $13 a$ & $43 b$ & $23 a$ & $56 a$ & $19 a$ & $12 \mathrm{a}$ & $16 a$ & $47 a$ & $0.45 a$ \\
\hline
\end{tabular}

Irrespective of variety, season or location (Table 6\&7), the best variety in terms of seed yield and yield components is IT98K-573-2-1, it producedhighest seed yield (75.8t/ha) followed by Oloyin Brown (72.4t/ha) while IT98K-205-8 had lowest yield across season and location. Seed weight, number of seed per plant, pod weight and shoot weight was better with IT98K-573-2-1(1,504.8g, 15.0, 60.0g116.6g) respectively. Ife brown attained $50 \%$ flowering at shorter days compared to other varieties while Oloyin Brown and IT97K-568-18 took longest days to attain $50 \%$ flowering in all seasons and locations. The result shows that forboth rainy seasons at Akure and Ado-Ekiti, shoot weight, number of pods, number of seeds, seed weight, pod weightand seed yieldwerebetter in Ado-Ekiti. However, in the late season, shoot weight, number of pods, number of seeds, seed weight, pod weight and seed yield were better in Akure (Table 8). In terms of seasons, result shows that the late season crop was betterin seed yield $(52.2 \mathrm{~kg} / \mathrm{ha}$ ) with a shorter day to attain 50\% flowering (44 days).However,the early rainy season crop had a higher shoot weight(114.0g),pod weight (50.0g), seed number (13) and seed weight (898g). In terms of location, Ado location was better in seed yield, seed weight, number of seeds and shoot weight.

Table 6: Cowpea performance across seasons in Akure and Ado-Ekiti locations, (WAP) Weeks after planting) Means along the column bearing same letters are not significantly different DMRT $(p<0.05)$.

\begin{tabular}{|c|c|c|c|c|c|c|c|c|c|c|c|c|c|c|}
\hline Location & $\begin{array}{c}\text { Number } \\
\text { of leaves } \\
\text { (7WAP) }\end{array}$ & $\begin{array}{c}\begin{array}{c}\text { Number } \\
\text { of } \\
\text { branches } \\
\text { (7WAP) }\end{array}\end{array}$ & $\begin{array}{l}\text { Vine } \\
\text { Length } \\
\text { (cm) } \\
\text { (7WAP) }\end{array}$ & $\begin{array}{c}\text { Number } \\
\text { of } \\
\text { nodules }\end{array}$ & $\begin{array}{c}\text { Shoot } \\
\text { biomass } \\
\text { (g) }\end{array}$ & $\begin{array}{c}\text { Number } \\
\text { of } \\
\text { peduncles }\end{array}$ & $\begin{array}{c}\text { Days } \\
\text { to } 50 \% \\
\text { Flowering }\end{array}$ & $\begin{array}{c}\text { Number } \\
\text { of pods }\end{array}$ & $\begin{array}{l}\text { Pod } \\
\text { Weight } \\
\text { (g) }\end{array}$ & $\begin{array}{c}\text { Pod } \\
\text { Length } \\
\text { (cm) }\end{array}$ & $\begin{array}{l}\text { Number } \\
\text { of seeds }\end{array}$ & $\begin{array}{c}100 \text { Seed } \\
\text { weight } \\
\text { (g) }\end{array}$ & $\begin{array}{c}\text { Seed } \\
\text { Yield } \\
(\mathrm{kg} / \mathrm{ha})\end{array}$ & $\begin{array}{c}\text { Harvest } \\
\text { index }\end{array}$ \\
\hline Akure & $93 a$ & $8 a$ & $96 a$ & $9 a$ & $103 \mathrm{~b}$ & $11 a$ & $45 a$ & $20 \mathrm{~b}$ & $48 \mathrm{~b}$ & $16 a$ & $12 \mathrm{a}$ & $17 a$ & $40 \mathrm{~b}$ & $0.38 a$ \\
\hline Ado-Ekiti & $85 b$ & $7 a$ & $91 \mathrm{ab}$ & $7 a$ & $122 a$ & $11 a$ & $48 a$ & $25 a$ & $63 a$ & $16 a$ & $13 a$ & $17 a$ & $58 a$ & $0.49 a$ \\
\hline
\end{tabular}

Table 7: Interaction between variety and season on performance of cowpea, (HI) Harvest index (WAP) Weeks after planting) Means along the column bearing same letters are not significantly different DMRT $(p<0.05){ }^{*}$ significant, ns not significant at $(p<0.05)$.

\begin{tabular}{|c|c|c|c|c|c|c|c|c|c|c|c|c|c|c|c|}
\hline Varieties & Season & $\begin{array}{c}\text { Number } \\
\text { of leaves } \\
\text { (7WAP) }\end{array}$ & $\begin{array}{c}\text { Number of } \\
\text { branches } \\
\text { (7WAP) }\end{array}$ & $\begin{array}{c}\text { Vine } \\
\text { Length } \\
\text { (cm) } \\
\text { (7WAP) }\end{array}$ & $\begin{array}{c}\text { Number } \\
\text { of } \\
\text { nodules }\end{array}$ & $\begin{array}{c}\text { Shoot } \\
\text { biomass } \\
\text { (g) }\end{array}$ & $\begin{array}{l}\text { Number of } \\
\text { peduncles }\end{array}$ & $\begin{array}{c}\text { Days } \\
\text { to } 50 \% \\
\text { Flowerig }\end{array}$ & $\begin{array}{c}\text { Number } \\
\text { of pods }\end{array}$ & $\begin{array}{c}\text { Pod } \\
\text { Weight } \\
\text { (g) }\end{array}$ & $\begin{array}{c}\text { Pod } \\
\text { Length } \\
\text { (cm) }\end{array}$ & $\begin{array}{l}\text { Number } \\
\text { of seeds }\end{array}$ & $\begin{array}{c}100 \\
\text { Seed } \\
\text { weight } \\
\text { (g) }\end{array}$ & $\begin{array}{c}\text { Seed } \\
\text { Yield } \\
(\mathrm{kg} / \mathrm{ha})\end{array}$ & HI \\
\hline \multicolumn{2}{|c|}{ Early season } & $79 b c$ & $6.3 a$ & $107 a b$ & $7.6 a$ & $96.6 \mathrm{bc}$ & $4.8 \mathrm{ab}$ & $47 \mathrm{ab}$ & $14.9 \mathrm{ab}$ & $33.7 \mathrm{~b}$ & $15.6 a$ & $12 \mathrm{a}$ & $15 \mathrm{ab}$ & $26.8 b$ & $0.28 \mathrm{a}$ \\
\hline
\end{tabular}


JOJ Horticulture \& Arboriculture

\begin{tabular}{|c|c|c|c|c|c|c|c|c|c|c|c|c|c|c|}
\hline IT98K-205-8 & $97 a b$ & $6.0 \mathrm{a}$ & $107 \mathrm{ab}$ & $7.6 \mathrm{a}$ & $96.6 \mathrm{bc}$ & $4.8 \mathrm{ab}$ & $47 a b$ & $14.9 \mathrm{ab}$ & $33.7 b$ & $15.6 \mathrm{a}$ & $12 a$ & $15 \mathrm{ab}$ & $26.8 b$ & $0.28 \mathrm{a}$ \\
\hline \multicolumn{15}{|c|}{ Ife Brown } \\
\hline IT96D-610 & $96 a b$ & $6.5 a$ & $97 \mathrm{bc}$ & $9.4 a$ & $111 \mathrm{ab}$ & $9.9 \mathrm{a}$ & $50 a$ & $20.2 \mathrm{a}$ & $44.5 \mathrm{ab}$ & $13.6 \mathrm{a}$ & $13 a$ & $20 a$ & $53.3 a$ & $0.48 \mathrm{a}$ \\
\hline IT98K-573-2-1 & $77 \mathrm{bc}$ & $8.3 \mathrm{a}$ & $95 \mathrm{bc}$ & $8.6 a$ & $146 a$ & $12 \mathrm{a}$ & $48 \mathrm{ab}$ & $21.3 \mathrm{a}$ & $67.6 \mathrm{a}$ & $13.4 \mathrm{a}$ & $15 \mathrm{a}$ & $19 \mathrm{a}$ & $65.1 \mathrm{a}$ & $0.45 \mathrm{a}$ \\
\hline Oloyin Brown & $101 \mathrm{a}$ & $7.6 \mathrm{a}$ & $123 a$ & $10 \mathrm{a}$ & $145 a$ & $11 \mathrm{a}$ & $52 \mathrm{ab}$ & $23.6 \mathrm{a}$ & $64.2 \mathrm{a}$ & $14.2 \mathrm{a}$ & $14 \mathrm{a}$ & $18 \mathrm{a}$ & $58.2 \mathrm{a}$ & $0.37 \mathrm{a}$ \\
\hline IT97K-568-18 & $107 a$ & $7.0 \mathrm{a}$ & $99 \mathrm{bc}$ & $10 \mathrm{a}$ & $121 \mathrm{ab}$ & $12 \mathrm{a}$ & $55 a$ & $21.2 \mathrm{a}$ & $45.4 \mathrm{ab}$ & $11.4 \mathrm{a}$ & $12 \mathrm{a}$ & $15 \mathrm{ab}$ & $34.8 \mathrm{ab}$ & $0.33 a$ \\
\hline IT98K-205-8 & $78 \mathrm{c}$ & $5.3 \mathrm{ab}$ & $77 \mathrm{c}$ & $7.2 \mathrm{a}$ & $92.9 \mathrm{bc}$ & $11 \mathrm{a}$ & $43 \mathrm{ab}$ & $19.6 \mathrm{ab}$ & $59.8 \mathrm{a}$ & $18.1 \mathrm{ab}$ & $11 \mathrm{a}$ & $17 \mathrm{a}$ & $31.4 \mathrm{~b}$ & $0.37 \mathrm{a}$ \\
\hline Ife Brown & $77 \mathrm{c}$ & $6.0 \mathrm{a}$ & $69 \mathrm{bc}$ & $6.4 \mathrm{a}$ & $89.6 \mathrm{bc}$ & $9 \mathrm{ab}$ & $40 \mathrm{ab}$ & $23.1 \mathrm{a}$ & $56.9 \mathrm{a}$ & $20.0 \mathrm{a}$ & $11 \mathrm{a}$ & $15 \mathrm{ab}$ & $37.7 \mathrm{~b}$ & $0.41 \mathrm{a}$ \\
\hline IT96D-610 & $84 \mathrm{bc}$ & $7.7 \mathrm{a}$ & $84 \mathrm{ab}$ & $6.0 \mathrm{a}$ & $82.0 \mathrm{bc}$ & $12 \mathrm{a}$ & $40 \mathrm{ab}$ & $18.7 \mathrm{ab}$ & $53.9 \mathrm{a}$ & $17.6 \mathrm{ab}$ & $11 \mathrm{a}$ & $16 a$ & 35.9 & $0.37 \mathrm{a}$ \\
\hline IT98K-573-2-1 & $94 \mathrm{ab}$ & $9.8 \mathrm{a}$ & $90 \mathrm{ab}$ & $8.2 \mathrm{a}$ & $92.9 \mathrm{bc}$ & $17 \mathrm{a}$ & $41 \mathrm{ab}$ & $25.8 \mathrm{a}$ & $43.5 \mathrm{ab}$ & $20.2 \mathrm{a}$ & $14 \mathrm{a}$ & $20 \mathrm{a}$ & $65.9 a$ & $0.71 \mathrm{a}$ \\
\hline Oloyin Brown & $111 \mathrm{a}$ & $10 \mathrm{a}$ & $97 \mathrm{ab}$ & $7.5 \mathrm{a}$ & $156 a$ & $15 a$ & $44 \mathrm{ab}$ & $28.0 \mathrm{a}$ & $61.0 \mathrm{a}$ & $22.3 \mathrm{a}$ & $13 a$ & $18 a$ & $68.0 \mathrm{a}$ & $0.52 \mathrm{a}$ \\
\hline Season (sn) & 4.1 & 2 & 9.3 & 3.1 & 5 & 4.1 & 4.3 & 3.1 & 5.2 & 4.1 & 3.3 & 2.2 & 2.4 & 0.6 \\
\hline Variety (var) & 11.2 & 1.2 & 13.4 & 3.3 & 2.4 & 3.1 & 1.7 & 1.3 & 9.5 & 2.1 & 4.1 & 1.6 & 8.3 & 0.3 \\
\hline Sn x Var & $*$ & Ns & $*$ & ns & $*$ & $*$ & ns & * & * & $*$ & * & $*$ & $*$ & * \\
\hline
\end{tabular}

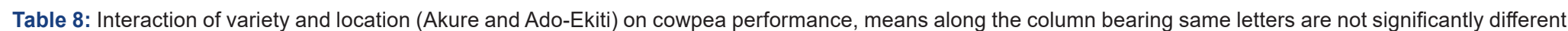
DMRT $(p<0.05)$ * significant, ns not significant at $(p<0.05)$.

\begin{tabular}{|c|c|c|c|c|c|c|c|c|c|c|c|c|c|c|c|}
\hline Varieties & Location & $\begin{array}{c}\text { Number } \\
\text { of leaves } \\
\text { (7WAP) }\end{array}$ & $\begin{array}{c}\text { Number } \\
\text { of } \\
\text { branches } \\
\text { (7WAP) }\end{array}$ & $\begin{array}{l}\text { Vine } \\
\text { Length } \\
\text { (cm) } \\
\text { (7WAP) }\end{array}$ & $\begin{array}{c}\text { Number } \\
\text { of } \\
\text { nodules }\end{array}$ & $\begin{array}{c}\text { Shoot } \\
\text { biomass } \\
\text { (g) }\end{array}$ & $\begin{array}{c}\text { Number } \\
\text { of } \\
\text { peduncles }\end{array}$ & $\begin{array}{c}\text { Days } \\
\text { to } 50 \% \\
\text { Flowering }\end{array}$ & $\begin{array}{c}\text { Number } \\
\text { of pods }\end{array}$ & $\begin{array}{c}\text { Pod } \\
\text { Weight } \\
\text { (g) }\end{array}$ & $\begin{array}{c}\text { Pod } \\
\text { Length } \\
\text { (cm) }\end{array}$ & $\begin{array}{l}\text { Number } \\
\text { of seeds }\end{array}$ & $\begin{array}{c}100 \\
\text { Seed } \\
\text { weight } \\
\text { (g) }\end{array}$ & $\begin{array}{l}\text { Seed } \\
\text { Yield } \\
\text { (kg/ } \\
\text { ha) }\end{array}$ & $\begin{array}{c}\text { Harvest } \\
\text { index }\end{array}$ \\
\hline Akure & & $71.9 \mathrm{~b}$ & $5.8 \mathrm{a}$ & $88.7 b c$ & $8.9 a$ & $92 \mathrm{bc}$ & $10 \mathrm{ab}$ & $45 a b$ & $19.2 \mathrm{a}$ & $42.6 \mathrm{ab}$ & 15.8 & $11 \mathrm{a}$ & $14.9 \mathrm{ab}$ & $29.8 b$ & $0.36 a$ \\
\hline IT98K-205-8 & & $93.9 \mathrm{ab}$ & $6.2 \mathrm{a}$ & $80.4 \mathrm{bc}$ & $6.7 \mathrm{a}$ & $100 \mathrm{~b}$ & $11 \mathrm{ab}$ & $41 \mathrm{ab}$ & $19.5 \mathrm{a}$ & $51.8 \mathrm{a}$ & $17.0 \mathrm{a}$ & $12 \mathrm{a}$ & $14.6 \mathrm{ab}$ & $31.1 \mathrm{ab}$ & $0.42 \mathrm{a}$ \\
\hline \multicolumn{16}{|c|}{ Ife Brown } \\
\hline IT96D-610 & & $89.1 \mathrm{ab}$ & $7.5 \mathrm{a}$ & $91.8 \mathrm{~b}$ & $7.9 \mathrm{a}$ & $94 \mathrm{bc}$ & $11 \mathrm{a}$ & $46 a b$ & $18.2 \mathrm{a}$ & $51.0 \mathrm{a}$ & $16.3 \mathrm{a}$ & $9 \mathrm{ab}$ & $17.2 \mathrm{a}$ & $35.7 \mathrm{ab}$ & $0.34 \mathrm{a}$ \\
\hline IT98K-573-2-1 & & $90.0 \mathrm{ab}$ & $9.3 \mathrm{a}$ & $96.3 \mathrm{~b}$ & $9.4 \mathrm{a}$ & $117 \mathrm{ab}$ & $14 \mathrm{a}$ & $43 \mathrm{ab}$ & $21.9 \mathrm{a}$ & $52.0 \mathrm{a}$ & $17.6 \mathrm{a}$ & $14 \mathrm{a}$ & $20.2 \mathrm{a}$ & $56.2 \mathrm{a}$ & $0.54 \mathrm{a}$ \\
\hline \multicolumn{2}{|c|}{ Oloyin Brown } & $106 a$ & $9.0 \mathrm{a}$ & $111 \mathrm{a}$ & $9.6 \mathrm{a}$ & $141 \mathrm{a}$ & $13 \mathrm{a}$ & $47 a$ & $22.6 \mathrm{a}$ & $47.0 \mathrm{ab}$ & $15.1 \mathrm{a}$ & $13 \mathrm{a}$ & $16.8 \mathrm{a}$ & $55.6 \mathrm{a}$ & $0.50 \mathrm{a}$ \\
\hline IT97K-568-18 & & $104 \mathrm{a}$ & $9.1 \mathrm{a}$ & $101 \mathrm{ab}$ & $8.8 \mathrm{a}$ & $107 \mathrm{~b}$ & $15 a$ & $49 a$ & $16.4 \mathrm{ab}$ & $43.1 \mathrm{ab}$ & $13.6 \mathrm{a}$ & $11 \mathrm{a}$ & $11.4 \mathrm{bc}$ & $30.5 \mathrm{ab}$ & $0.27 \mathrm{a}$ \\
\hline \multicolumn{16}{|c|}{ Ado-Ekiti } \\
\hline IT98K-205-8 & & $92.2 \mathrm{ab}$ & $5.7 \mathrm{a}$ & $94.9 \mathrm{ab}$ & $4.4 \mathrm{a}$ & $101 \mathrm{~cd}$ & $12 \mathrm{a}$ & $46 \mathrm{ab}$ & $13.5 \mathrm{c}$ & $55.0 \mathrm{bc}$ & $19.0 \mathrm{a}$ & $12 \mathrm{a}$ & $18.0 \mathrm{a}$ & $27.6 \mathrm{bc}$ & $0.27 \mathrm{a}$ \\
\hline Ife Brown & & $73.2 \mathrm{~b}$ & $5.7 \mathrm{a}$ & $71.7 \mathrm{bc}$ & $5.5 \mathrm{a}$ & $82.5 \mathrm{~d}$ & $6.0 \mathrm{ab}$ & $43 \mathrm{~b}$ & $22.4 \mathrm{~b}$ & $67.3 \mathrm{~b}$ & $12.8 \mathrm{ab}$ & $9 \mathrm{ab}$ & $18.8 \mathrm{a}$ & $39.1 b$ & $0.48 \mathrm{a}$ \\
\hline IT96D-610 & & $91.8 \mathrm{ab}$ & $6.7 \mathrm{a}$ & $80.0 \mathrm{~b}$ & $7.3 \mathrm{a}$ & $102 \mathrm{~cd}$ & $11 \mathrm{a}$ & $43 \mathrm{~b}$ & $22.0 \mathrm{~b}$ & $45.9 \mathrm{~cd}$ & $14.1 \mathrm{a}$ & $14 \mathrm{a}$ & $19.3 a$ & $62.3 \mathrm{ab}$ & $0.59 a$ \\
\hline IT98K-573-2-1 & & $74.7 \mathrm{~b}$ & $8.7 \mathrm{a}$ & $84.6 \mathrm{~b}$ & $6.7 \mathrm{a}$ & $126 \mathrm{c}$ & $15 a$ & $48 \mathrm{ab}$ & $27.0 \mathrm{ab}$ & $63.3 \mathrm{~b}$ & $15.1 \mathrm{a}$ & $16 \mathrm{a}$ & $18.7 \mathrm{a}$ & $84.1 \mathrm{a}$ & $0.68 \mathrm{a}$ \\
\hline \multicolumn{2}{|c|}{ Oloyin Brown } & $104 \mathrm{a}$ & $8.6 a$ & $107 a$ & $7.5 \mathrm{a}$ & $170 \mathrm{a}$ & $12 \mathrm{a}$ & $51 \mathrm{ab}$ & $32.1 \mathrm{a}$ & $82.0 \mathrm{a}$ & $18.3 a$ & $13 a$ & $18.9 a$ & $78.1 \mathrm{a}$ & $0.44 \mathrm{a}$ \\
\hline IT97K-568-18 & & $72.5 \mathrm{~b}$ & $5.1 \mathrm{a}$ & $107 \mathrm{a}$ & $9.9 \mathrm{a}$ & $149 \mathrm{~b}$ & $8.0 \mathrm{a}$ & $56 a$ & $32.1 \mathrm{a}$ & $63.5 \mathrm{~b}$ & $15.0 \mathrm{a}$ & $11 \mathrm{a}$ & $17.1 \mathrm{a}$ & $54.1 \mathrm{ab}$ & $0.46 a$ \\
\hline Variety (Var) & & 11.2 & 1.1 & 13.4 & 3.1 & 2.4 & 3.1 & 1.7 & 1.3 & 9.5 & 2.1 & 4.1 & 1.6 & 12.3 & 0.3 \\
\hline Location (Ln) & & 6.1 & 2.2 & 4.3 & 1.2 & 9.7 & 1 & 2.3 & 2.4 & 7.7 & 2.1 & 1.8 & 1.3 & 11.2 & 0.5 \\
\hline Var x Ln & & $\mathrm{ns}$ & Ns & ns & ns & $*$ & $*$ & ns & $*$ & $*$ & ns & $*$ & ns & * & ns \\
\hline
\end{tabular}

\section{Discussion}

Differences were obtained in the performance of six cowpea varieties in terms of capacity for biomass accumulation, seed yields and yield components when sown as early and late rainy season crops. There were differences in the weather conditions of the early part of the rainy season (early vegetative phase of cowpea growth) and in the later part of the late cropping season (terminal drought situation which occurred during the reproductive stage of cowpea growth). The variations in weather conditionsappeared to have significantly affected growth and yield characters of cowpea varieties sown as early and late rainy season crops in both Akure and Ado-Ekiti locations. However, within a growing season, varieties differed in their responses to prevailing weather conditions and in growth and yield characters. The differences in growing environmental conditions during the pre- and post- floweringin the rainy and late rainy seasons, seemed to have regulated seed set and seed yield in cowpea. The results showed that cowpea varieties planted in the late rainy season were early to mature with respect to days to attain 50\% flowering and seed yield production compared with the early rainy season crop. 
Among the cowpea varieties, differences in growth and yield can be attributed to prevailing weather conditions of the growing seasons. Despite the rapid increases in vine length and higher shoot biomass that was obtained for the early season crop, in particular, seed yields were higher for the late rainy season crop. This observation follows from the higher efficiency of assimilate production and partitioning to reproductive sinks especially the seeds in late season cowpea.The shortened growth duration and low shoot biomass are attributable to the effect of the supra-optimal temperature and dry atmosphere of the late season which ranged between 31.8 to $34.50 \mathrm{C}$ and 2.6 to $3.0 \mathrm{KPa}$ [7]. In the late season in particular, cowpea flowered (anthesis), set and filled seeds and matured during periods of high soil and air temperatures and atmospheric dryness. These weather factors would have promoted rapid soil water depletion while the low rainfall-enhanced status of soil moisture reserve would possiblyimply inability of soil profile moisture to meet crop demand hence earliness to maturity and low biomass yields. Barron et al. [11] showed that dry spell with high evapotranspiration demand may lead to decreases in the yield of crops up to $40 \%$ because of insufficientsoil water supply during grain filling stage. The late season cowpea commenced flowering earlier by about 10 days over the early rainy season crop. The shortened reproductive growth phase along with the unfavourable prevailing weather conditions could have shortened the period of assimilate production for seed filling. In crops, obtainable seed yields are most of the times attributed to assimilation production and partitioning efficiencies $[2,11]$.

The significant differences in growth attributes, such as vine length, number of leaves and branches observed among the cowpea varieties may be attributed to genotypic characters. This might explain the superiority of IT98K-573-2-1 and Oloyin Brown for most of the growth parameters measured. Although cowpea is considered a drought tolerant crop, water stress at vegetative or reproductive stages of growth is a frequent cause of yield fluctuation [2].In this study, seed yield of cowpea differed between the early and late rainy season crop. The reductions were found in yield components such as number of pods per plant, number of seeds per pod and seed weight. This study obtained differences in cowpea growth parameters such as increase in leaf area, shift in dry matter partitioning in favor of shoot biomass and increase in pod number. Pressman et al. [18] attributed the loss in seed yield due drought to low seed setting efficiency and short seed filling time for pods. Seed/plant is a trait which is influenced by environmental factors and this attribute is an important yield component that is sensitive to soil moisture deficit. The post-flowering soil and atmospheric moisture deficits would have implications for seed yield production in late rainy season cowpea. These stress factors are known to induce embryo abortion while low assimilate enhanced poor seed filling $[12,18]$.Pressman et al. [12] attributed low crop yields to extreme weather conditions which enhanced dehydration of pollen and poor pollination and embryo abortion.
The results indicate that seed yield variation may be related to the amount of moisture available for crop use especially during the reproductive growth (seed filing phase). Under non-waterstressed conditions of the rainy season, cowpea gave higher biomass yields and longer vegetative and reproductive growth than under water-stressed conditions of the late rainy season. In the late rainy season crop, the vegetative growth phase occurred during periods when soil moisture was adequate.However, the improved seed yield in late season cowpea maybe related to the exploitation of substantial soil water prior to grain filling and presumably from the dry weather (air) during seed set and seed filling periods which would have enhanced assimilate partitioning to reproductive structures and efficiency of seed setting [2]. The high intensities of soil moisture deficits and supraoptimal soil temperatures which characterized the late sowing season in the tropical rainforest environment elicit responses in the growth and yield of arable crops [7]. The regulation of plant biomass especially the size of leaf area/plant by drought in order to maintain transpiration per unit area of leaf is reported for droughted crops [7]. In the late season, the cowpea cultivars appeared to have escaped soil and air drought and temperature stresses. Earliness via the relative short duration of reproductive growth in late season cowpea in this study would provide drought escape opportunity.The physiological advantage of early maturity in crops is known $[2,19]$. Selection and growing early maturing cowpea varieties may therefore be advantageous under low soil moisture conditionsgoing by their ability to complete life cycle before higher degree of moisture deficit stress and high temperatures occurred. Craufurd and Qi [9] and Agele\&Agbi[2] reported that the number of seeds per plant could decrease through promotion of flower abortion and pod shedding under unfavorable extreme weather events in soybean and rice.

In the early and late rainy season crop in Akure, IT98K-573-2-1 and Oloyin Brown gave the highest seed yields $(56.9 \mathrm{k} / \mathrm{ha}$ and $72 \mathrm{~kg} / / \mathrm{ha}$ ) while the highest seed yield was obtainedin theearly and late rainy late seasons crop inAdo-EkitifromIT98K-573-2-1 andOloyin Brown (103.4k/ha and $77.4 \mathrm{~kg} / \mathrm{ha}$ ) respectively. In contrast, the lowest seed yields for the early and laterainy season crops in Akure were obtained from Ife Brown and IT98K-205-8 (27.4kg/ha and $36 \mathrm{~kg} /$ harespectively whileIT96D-610 and IT98K-205-8 gave the lowest seed yields in the early and late rainy seasons in Ado-Ekiti respectively. Result showed that cowpea varieties that were planted as early rainy season crops were better in Ado-Ekiti $(63.7 \mathrm{~kg} / \mathrm{ha})$ while the late rainy season crop gave higher yields $(56.0 \mathrm{~kg} / \mathrm{ha})$ in Akure compared with the early rainy season crop. Between the two seasons and at both locations, cowpea planted in the late season out yielded the early rainy season crops. The best performing variety was IT98K-573-2-1 (75.8kg/ha) while the least wasIT98K-205-8 (31.6kg/ha). The highest seed yields recorded may be attributed to better ability of the varieties to adapt to the environmental conditions of the study areas. Drought and heat stresses are important environmental conditions influencing growth and 
yield of crops while climate change-enhanced hydrothermal stresses have been reported as a crucial limit to global crop productivity and food security $[7,25]$.

\section{Conclusion}

Six cowpea varieties were evaluated with respect to growth and yield when grown as early rainy and late rainy season crops under field conditions inthe rainforest and forestsavanna transition zones of south west Nigeria. In the sites of study, the sowing seasons (early and late seasons) differed in weather conditions characterized by varying rainfall amount and distribution, intensities solar radiation and vapour pressure deficits (vpd), minimum and maximum temperatures. The respective early and later parts of the early and late rainy seasons were characterized by intermittent and terminal dry spell (drought) situations. Therefore, sowing cowpea in the early and late seasons subjected their pre- and postflowering development phases to contrasting environmental conditions. These conditions appeared to have affected biomass accumulation, lowering and seed yield characters in the cowpea cultivars evaluated. Cowpea varieties differed in the number and weight of pods and seeds. Based on the yield performance of the varieties as early and late rainy season crops, IT98K-573-2-1 gave the highest seed yield (56.9) and (103.4 k/ha) respectively while the highest seed yield in the late rainy season of Akure and AdoEkiti location was Oloyin Brown (72.0 and 77.4t/ha) respectively. Similarly, the lowest seed yield recorded for the rainy season crop at both location for Ife brown and IT98K-205-8 (27.4 and 23.3k/ ha) for Akure and Ado-Ekiti respectively. For the late season crops, lowest seed yields were obtained for IT98K-205-8 at 36 and $25.4 \mathrm{k} /$ ha for both locations. This may indicate the inability of IT98K-205-8 to tolerate (adapt) the unfavorable weather conditions of the late season. The highest seed yields recorded for IT98K-573-2-1 and Oloyin Brown may be attributed to its characteristics ability to mature within 60 days of sowing before the occurrence of severe hydrothermal stresses of the season. Cowpea varieties, IT98K-573-2-1 and Oloyin Brown both gave the highest yield in both seasons and locations and were most suitable for cultivation in the study area.

\section{References}

1. Food and Agriculture Organization (FAO) (2014) Definition and classification of commodities. Pulses and derived products.

2. Agele SO, Agbi AM (2012) Growth and yield responses of selected cowpea (Vigna unguiculata L.Walp) cultivars to weather and soil factors of the growing seasons. Trade Science Inc, India (RRBS) 7(7): 265-276.

3. International Institute of Tropical Agriculture (IITA) (1998) Cowpea Production and Utilization. In: Crops and Farming System.

4. Purseglove JW (1988) Tropical Crops. Dicotyledons. Longman, London pp.232.

5. Graham PH, Vance CP (2000) Legumes: importance and constraints to greater use. Plant Physiol 131: 872-8771.
6. Agele SO, Adenawoola AR, Doherty M (2004) Growth response of soybean lines to contrasting photo thermal and soil moisture regimes in a Nigerian tropical rain forest Int J. Biotronics 33: 49-64.

7. Agele SO, Iremiren GO, Ojeniyi SO (2011) Evapotranspiración, wáter use efficiency and yield of rainfed and irrigated tomato in the dry season in a humid rainforest zone of Nigeria. International J. Biology \& Agric. Sci 13: 469-476.

8. Agele SO, Ajayi AJ, Olawanle FM (2017) Effects of watering regime and rhizobium inoculation on growth, functional and yield traits of four legume species. Int. J. Plant \& Soil Sci 17(4): 1-15.

9. Craufurd N, Qi P (1996) Effect of plant population density on dry matter partitions and yield in short duration cowpea (Vigna unguiculata) grown in the tropics. J. Agric. Sci 127: 89-96.

10. Agele SO (2003) Sunflower responses to weather variations in rainy and dry cropping seasons in a tropical rainforest zone. Int. J. Biotronics 32: 17-33.

11. Baron J, Rockstrom J, Gichuki F, Hatibu N (2003) Dry spell analysis for Maize yield for two semi-arid locations in East Africa. J. Agric. For. Meteor 117(1-2): 23-37.

12. Pressman E, Peet MM, Pharr DM (2002) The effect of heat stress on tomato pollen characteristics associated with changes in carbohydrate concentration in the developing anthers. Annal Bot 90(5): 631-636.

13. Sato S, Peet MM, Thomas JF (2002) Determining critical pre- and post-anthesis periods and physiological processes in Lycopersicum esculentum Mill exposed to moderately elevated temperatures. J. Exp. Bot 53(371): 1187-1195.

14. Wardlaw IF (2002) Interaction of drought and chronic high temperature during kernel feeling in wheat in a controlled environment. Annal Bot 90(4): 469-476.

15. Bell MJ, Wright GC (1998) Groundnut growth and development in contrasting environment. (Growth and plant density responses). Exp. Agric 34: 99-112.

16. Bradford M, Hsaio T (1979) Groundnut growth and development in constrasting environment. (Heat unit accumulation and photo-thermal effect on harvest index). Exp. Agric 34:113-124.

17. Zinsemeier C, Joeng BR, Boyer JS (1999) Starch and the control of kernel number in maize at low water potential. Plant Physiol 121: 2536.

18. Agele SO (2006) Weather and seasonal effects on growth, seed yield and soluble carbohydrate in selected maize cultivars in the humid area of Nigeria. African J. Agric. Res 1(4): 101-110.

19. San Jose JJ, Bracho R, Montes R, Nikonova N (2002) Comparative energy exchange from cowpea (Vigna uguiculata L, Walp) cvs, tc-9-6 and M-28-6-6) with difference in canopy architectures and growth durations at the Orinoco Llanos. J Agric For Meteor 99: 1-23.

20. Ntare BR, Williams JH, Nduguru BJ (1988) Effects of seasonal variations in temperature and cultivar on yield and yield determination of irrigated groundnut (Arachis hypogaea) during the dry season in the Sahel of West Africa. J Agric Sci 131: 439-448.

21. Saini HS, Westgate ME (2000) Reproductive development in grain crops during drought. Adv Agron 68: 55-96.

22. Walkey A, Black IA (1934) An examination of Degtjareff method for determining soil organic matter and a proposed modification of the chromic acid titration. Methods Soil Sci 37(1): 29-37.

23. Jackson ML (1962) Soil Chemical Analysis. Prentice-Hall Inc, New Jersey, USA. 
24. Bray RH, Kurtz LT (1945) Determination of total organic and available forms of phosphorus in soils. Soil Sci 59(1): 39-45.

25. Omotosho J, Bayo, Agele SO, Balogun IA, Adefisan EA (2013) Climate variability, crop-climate modeling and water ecophysiology research: implications for plant's capacities for stress acclimation, yield production and food security. Global J. Plant Ecophysiol 3(2): 56-69.
This work is licensed under Creative Commons Attribution 4.0 License DOI: 10.19080/JOJHA.2018.01.555575 